Syntax Fusion : Jurnal Nasional Indonesia

e-ISSN : 2775-4440

Vol. 1, No. 9, September 2021

\title{
MENINGKATKAN HASIL BELAJAR TENTANG PENGURANGAN \\ BILANGAN BULAT DENGAN MENGGUNAKAN MEDIA BALOK GARIS BILANGAN PADA SISWA KELAS V SD NEGERI 1 TELUK BETUNG
}

\author{
Alia Mayang \\ SDN 1 Teluk Betung \\ Email: aliamayang4@gmail.com
}

\begin{abstract}
Abstrak
Penelitian ini dilatarbelakangi oleh kesulitan siswa dalam menerima materi yang masih abstrak dan situasi pembelajaran yang kurang menarik, belajar yang membosankan, siswa terlihat kurang antusias mengikuti pembelajaran dan mematikan kreativitas siswa yang berdampak pada hasil belajar yang kurang optimal. Hal ini disebabkan oleh beberapa faktor salah satunya yaitu karena siswa masih berada dalam tahapan operasi konkret, penyajian materi yang kurang melibatkan intelektual, emosional, dan fisik, dalam kegiatan belajar dan pembelajaran lebih banyak berfokus pada penguasaan atas isi buku teks dan minimnya penggunaan media dan alat peraga, pelaksanaan pembelajaran masih monoton dan siswa tidak terlibat secara aktif serta minimnya bimbingan guru dalam mengatasi kesulitan siswa.Berdasarkan permasalahan tersebut, maka tujuan penelitian yang hendak dicapai adalah untuk meningkatkan Hasil Belajar tentang pengurangan bilangan bulat dengan menggunakan media balok garis bilangan pada siswa kelas V SD Negeri 1 Teluk Betung Kecamatan Karau Kuala. Subjek penelitian ini adalah Siswa Kelas V SD Negeri 1 Teluk Betung yang berjumlah 15 orang.Pengumpulan data dilakukan melalui observasi dan tes sedangkan analisis data digunakan analisis deskriftif kuantitatif dan kualitatif. Hasil penelitian menunjukan bahwa : 1) Hasil belajar siswa diketahui bahwa rata-rata kelas untuk pertemuan pertama adalah 8,53 diatas indikator ketuntasan belajar dengan ketuntasan klasikal sebanyak 13 orang (86,66\%) dengan perolehan nilai berkisar antara 6 sampai 10 dan untuk siklus 2 naik mernjadi 9,20 diatas indikator ketuntasan belajar dengan ketuntasan klasikal sebanyak 15 orang (100\%) dengan perolehan nilai berkisar antara 8 sampai 10, 2) Peningkatan aktivitas siswa dalam kelompok pada siklus 1 hanya 7,74 meningkat menjadi7,97 di siklus 2. Kesimpulannya adalah penggunaan Media balok garis bilangan pada pengurangan bilangan bulat dapat meningkatkan hasil belajar siswa kelas V SD Negeri 1 Teluk Betung Kecamatan Karau Kuala Kabupaten Barito Selatan.
\end{abstract}

Kata Kunci : Hasil Belajar, Media, Alat Peraga, Balok Garis Bilangan

\section{Pendahuluan}

Perkembangan ilmu pengetahuan dan teknologi yang begitu cepat dalam berbagai aspek kehidupan menjadi tantangan bangsa dalam mem-persiapkan generasi masa depan. Pendidikan sebagai bagian penting dalam kehidupan bermasyarakat baik itu kehidupan individu, keluarga, bangsa, dan negara. Untuk itu 
peran pendidikan sangat penting untuk menyiapkan sumber daya manusia (SDM) yang mempunyai kemampuan intelektual dan moralitas. Pendidikan merupakan suatu kebutuhan pokok yang mutlak diperlukan manusia untuk hidup normal di tengah-tengah masyarakat. Salah satu upaya yang dilakukan pemerintah dalam meningkatkan mutu pendidikan yaitu melalui lembaga pendidikan baik formal maupun non formal.

Berdasarkan Undang-Undang Nomor 20 Tahun 2003 BAB I pasal 1, bahwa pendidikan adalah usaha sadar dan terancana untuk mewujudkan suasana belajar dan proses pembelajaran agar peserta didik secara aktif mengembangkan potensi dirinya untuk memiliki kekuatan spiritual keagamaan, pengendalian diri, kepribadian, kecerdasan, akhlak mulia, serta keterampilan yang diperlukan dirinya, masyarakat, bangsa dan negara. (Mendiknas.2003:2).

Peraturan Menteri Pendidikan Nasional No 22 Tahun 2006 tentang standar isi untuk satuan pendidikan dasar dan menengah menyatakan bahwa kurikulum dilaksanakan dengan menegakkan lima pilar belajar, yaitu : (a) belajar untuk beriman dan bertakwa kepada Tuhan Yang Maha Esa, (b) belajar untuk memahami dan menghayati, (c) belajar untuk mampu melaksanakan dan berbuat secara efektif, (d) belajar untuk hidup bersama dan berguna bagi orang lain, dan (e) belajar untuk membangun dan menemukan jati diri, melalui proses pembelajaran yang aktif, kreatif, efektif, dan menyenangkan. (Depdiknas:2006:7)

Sesuai dengan pilar belajar tersebut, belajar bukanlah menghafal sejumlah fakta-fakta atau informasi. Belajar adalah berbuat, memperoleh pengalaman tertentu sesuai dengan tujuan yang diharapkan. Karena itu, strategi pembelajaran harus mendorong aktivitas siswa. Aktivitas siswa tidak dimaksudkan aktivitas fisik, akan tetapi juga meliputi aktivitas yang bersifat psikis seperti mental. Guru sering lupa dengan hal ini. Banyak guru yang terkecoh oleh sikap pura-pura aktif padahal sebenarnya tidak (Sanjaya, $2007: 130$ ).

Matematika sebagai mata pelajaran yang dipelajari di sekolah memiliki peranan cukup besar guna menumbuhkembangkan kemampuan-kemampuan dan membentuk pribadi siswa serta berpadu pada perkembangan ilmu peng-etahuan dan teknologi. Matematika juga penting sebagai alat bantu, sebagai ilmu, sebagai pembimbing pola pikir maupun pembentukan sikap. Tak dapat dipungkiri bahwa matematika memiliki banyak kegunaan, matematika perlu diberikan kepada peserta didik pada setiap jenjang pendidikan.

Pembelajaran matematika merupakan proses pemberian pengalaman belajar kepada peserta didik melalui serangkaian kegiatan yang terencana sehingga siswa memperoleh kompetensi tentang bahan matematika yang dipelajari. Salah satu komponen yang menentukan ketercapaian kompetensi adalah penggunaan strategi pembelajaran matematika, alat peraga, dan media yang sesuai dengan topik yang sedang dibicarakan, tingkat perkembangan intelektual siswa, keterkaitan dengan kehidupan siswa sehari-hari, serta peng-embangan dan pemahaman penalaran matematis. (Muhsetyo.2008.1.26).

Kurikulum Tingkat Satuan Pendidikan (KTSP) 2006 pada mata pelajaran matematika kelas $\mathrm{V}$ materi tentang bilangan salah satunya adalah menjumlahkan dan mengurangkan bilangan bulat.

Kondisi riil yang terjadi di SD Negeri 1 Teluk Betung adalah rendahnya nilai pelajaran matematika yang diperoleh siswa kelas $\mathrm{V}$ pada nilai ulangan harian. Prestasi yang rendah itu terjadi juga pada materi pokok operasi pengurangan 
bilangan bulat . Hal ini dapat diketahui dari nilai rata-rata prasiklus pada materi pengurangan bilangan bulat perolehan nilai rata-rata 5,32 dibawah ketuntasan minimal 6,5 dengan ketuntasan klasikal 59,09\%.

Berdasarkan hasil diskusi dengan supervisor terungkap bahwa kesulitan belajar ini karena siswa masih berada dalam tahapan operasi konkret, penyajian materi yang kurang melibatkan intelektual, emosional, dan fisik, dalam kegiatan belajar dan pembelajaran lebih banyak berfokus pada penguasaan atas isi buku teks dan minimnya penggunaan media dan alat peraga, pelaksanaan pembelajaran masih monoton dan siswa tidak terlibat secara aktif serta minimnya bimbingan guru dalam mengatasi kesulitan siswa. Semua hal ini telah menyebabkan siswa kesulitan dalam menerima materi yang masih abstrak dan situasi pembelajaran yang kurang menarik, belajar yang membosankan, siswa terlihat kurang antusias mengikuti pembelajaran dan mematikan kreativitas siswa yang berdampak pada hasil belajar yang kurang optimal.

Salah satu model pembelajaran yang dapat meningkatkan efektivitas pembelajaran adalah dengan pembelajaran kooperatif. Pembelajaran kooperatif merupakan model pembelajaran yang meliputi suatu kelompok kecil siswa yang bekerja sebagai tim untuk menyelesaikan sebuah masalah, menyelesaikan suatu tugas, atau mengerjakan sesuatu untuk tujuan lainnya Pembelajaran kooperatif diterapkan diterapkan karena beberapa alasan pertama kelompok heterogen memberikan kesempatan untuk saling mengajar (peer tutoring). kedua, kelompok ini meningkatkan relasi dan interaksi antar ras, etnik, dan gender. Ketiga, kelompok hetrogen memudahkan pengelolaan kelas karena dengan adanya satu orang yang berkemampuan tinggi, guru mendapat satu asisten untuk tiap tiga orang. (Anita.2006:42).

Model pembelajaran ini mengutamakan kerja sama diantara siswa dan saling ketergantungan dalam struktur tugas, tujuan dan hadiah untuk mencapai tujuan pembelajaran. Dalam pelaksanaannya guru menyajikan informasi akademik baru kepada siswa, siswa dalam suatu kelas dibentuk dalam kelompok-kelompok belajar yang heterogen yaitu terdiri dari laki-laki dan perempuan, berasal dari berbagai suku, yang memiliki kemampuan tinggi, sedang, dan rendah yang beranggotakan antara 4-5 orang setiap kelompok, menggunakan lembar kerja siswa (LKS) atau perangkat pembelajaran lain untuk menuntaskan materi pelajaran, masing-masing anggota kelompok berdiskusi untuk memahami bahan pelajaran dan melakukan kegiatan yang diperintahkan. Pada akhir pertemuan secara individual siswa diberikan tes untuk mengetahui tingkat keberhasilan belajar siswa dan masing-masing kelompok diberi penghargaan. (Anita.2006:3).

Agar siswa tidak mengalami verbalisme dan menimbulkan miskonsepsi serta lebih memahami konsep bilangan bulat menurut peneliti perlu diciptakan lingkungan belajar kelompok dengan bantuan media balok garis bilangan bulat. Media yang digunakan dalam pembelajaran ini dapat memperjelas materi pelajaran dan mencegah terjadinya verbalisme pada diri siswa, pembelajaran akan lebih menarik bila siswa gembira belajar karena mereka merasa tertarik dan mengerti apa yang dipelajarinya. Dari fungsinya memberikan motivasi belajar, media ini akan memberikan semangat baru dan senang mempelajari matematika. Dengan semangat dan minat yang tumbuh dari diri siswa sendiri diharapkan dapat meningkatkan hasil belajar siswa. Konsepsi pembelajaran aktif, kreatif, efektif dan menyenangkan 
dapat dilaksanakan dan diperoleh hasil belajar yang optimal baik dari segi kognitif, afektif, dan psikomotorik. (Masrukan.2004:31).

\section{Metode Penelitian}

Yang menjadi subjek dalam penelitian ini adalah seluruh siswa kelas V SD Negeri 1 Teluk Betung Kecamatan Karau Kuala Kabupaten Barito Selatan tahun pelajaran 2017/2018 berjumlah 15 orang terdiri dari 7 orang laki-laki dan 8 orang perempuan pada mata pelajaran matematika konsep pengurangan bilangan bulat.

Waktu pelaksanaan penelitian tanggal 09 Oktober 2017 sampai dengan tanggal 29 Oktober 2017. Adapun jadwal pelaksanaan sesuai dengan jadwal pelajaran di sekolah yaitu sebagai berikut:

Tabel 3.1: Jadwal Pelaksanaan Kegiatan Perbaikan Pembelajaran

\begin{tabular}{ccclcl}
\hline No & Tanggal & Mapel & Pembelajaran & Kelas & Keterangan \\
\hline 1 & 09 Oktober 2017 & Matematika & RPP I & V & Siklus 1 \\
2 & 29 Oktober 2017 & Matematika & RPP II & V & Siklus 2 \\
& & & & & \\
\hline
\end{tabular}

Dalam pelaksanaan Penelitian Tindakan Kelas (PTK) ini, peniliti dibimbing oleh teman sejawat. Teman sejawat adalah guru yang berkompeten dalam bidang mata pelajaran matematika dan sudah memiliki seritifikat pendidik untuk membimbing peneliti dalam menyusun RPP perbaikan dan melakukan praktek perbaikan pembelajaran di kelas.

Prosedur yang digunakan dalam penelian ini adalah penelitian tindakan kelas (classroom actions research), yang menurut Kemmis dan Taggart (Harsoyo. 2001:24) pengertian tindakan kelas adalah "suatu bentuk self inquiri kolektif yang dilakukan oleh partisipan di dalam situasi sosial atau pendidikan yang mereka lakukan, serta mempertinggi pemahaman mereka terhadap praktik dan situasi di mana praktik pembelajaran dilaksanakan".

Penelitian tindakan kelas berdasarkan Aqib (2006:16) yaitu penelitian yang dilakukan guru di kelas atau di sekolah tempat mengajar, dengan penekanan pada penyempurnaan atau peningkatan praktik dan proses dalam pembelajaran.

Kemudian pendapat Arikunto (2007:3) menyatakan pula penelitian tindakan kelas merupakan suatu pencermatan terhadap kegiatan belajar berupa sebuah tindakan, yang sengaja dimunculkan dan terjadi dalam sebuah kelas secara bersama.

Berdasarkan pengertian tersebut dapatlah disimpulkan bahwa penelitian tindakan kelas adalah suatu bentuk penelitian melalui refleksi diri terhadap praktik pembelajaran di kelas dengan tujuan memperbaiki dan meningkatkan kondisi serta kualitas pembelajaran bagi peningkatan hasil belajar siswa melalui tindakan tertentu.

Penelitian tindakan kelas dilakukan melalui proses pengkajian yang berdaur, yang terdiri dari 4 tahap, yaitu merencanakan, melakukan tindakan, mengamati, dan melakukan refleksi. Tiap siklus terdiri dari perencanaan, tindakan, observasi dan evaluasi, serta refleksi.

Dalam penelitian tindakan kelas guru melaksanakan kegiatan pembelajaran kepada siswa yang dilakukan dalam siklus-siklus. Pada setiap siklus dilaksanakan kegiatan pembelajaran, dimulai perencanaan, mengemukakan permasalahan, 
menetapkan langkah-langkah pemecahan masalah sampai kepada evaluasi, analisa dan refleksi. semua tersebut diulang-ulang melalui siklus-siklus yang dikehendaki. Melalui siklus-siklus ini, akhirnya guru dapat mengambil kesimpulan dan refleksi terhadap hasil penelitian.

Tahapan Penelitian Tindakan Kelas :

a. Perencanaan/Persiapan

Perencanaan merupakan tahapan awal yang dilakukan guru sebelum melakukan tindakan. Pada tahapan perencanaan peneliti merencanakan segala tindakan yang akan dilakukan dalam upaya meningkatkan hasil belajar siswa, perbaikan aktivitas siswa dalam mengikuti pembelajaran serta perbaikan kemampuan dan keterampilan guru dalam mengelola pembelajaran. Kegiatan yang dilakukan yaitu : membuat rencana pembelajaran beserta skenario tindakan yang akan dilaksanakan, menyiapkan materi, sarana dan fasilitas yang diperlukan, menyiapkan cara merekam dan cara menganalisis data yang berkaitan dengan peningkatan hasil belajar, perbaikan aktivitas siswa, kemampuan dan keterampilan guru dalam mengelola pembelajaran, serta memilih satu rekan sebagai observer.

b. Pelaksanaan tindakan

Pada tahapan ini peneliti melakukan segala perencanaan yang telah dibuat yaitu penerapan model pembelajaran dengan menggunakan media balok garis bilangan. Semua aktivitas pembelajaran dimaksudkan untuk perbaikan dan pengoptimalan aktivitas pembelajaran yang sedang dilaksana-kan dengan sasaran meningkatnya hasil belajar siswa.

c. Observasi

Observasi ini bertujuan mengumpulkan data-data yang diperlukan untuk menguji hipotesis. Dalam observasi ditujukan untuk memantau proses dan dampak perbaikan yang direncanakan. Proses dan dampak yang teramati direkam dan didokumentasikan selanjutnya dianalisis dengan menyeleksi, mengelompokkan data, mendeskripsikan data dalam bentuk narasi, tabel, grafik, serta menyimpulkannya dalam bentuk pernyataan.

d. Refleksi

Pada tahap ini peneliti menganalisa hasil pelaksanaan penelitian tindakan kelas, kemudian direfleksi melalui analisis, sintesis terhadap apa yang dicapai, apa yang belum dicapai, serta apa yang perlu diperbaiki lagi pada siklus berikutnya. Kesimpulan dan informasi yang didapat pada analisis data dan refleksi digunakan untuk membuat perencanaan tindak lanjut.

\section{Hasil Dan Pembahasan}

\section{a. Hasil Pelaksanaan Tindakan Kelas Siklus 1}

a. Hasil tes belajar siswa

Dari hasil tes yang dilaksanakan pada pertemuan 1 dapat digambarkan perolehan nilai hasil belajar sebagai berikut :

Tabel 4.1: Nilai Tes Hasil Belajar Siklus 1

\begin{tabular}{ccccccc}
\hline \hline \multirow{2}{*}{ No } & $\begin{array}{c}\text { Inisial Nama } \\
\text { Siswa }\end{array}$ & $\begin{array}{c}\text { Tes } \\
\text { Awal }\end{array}$ & $\begin{array}{c}\text { Ketun- } \\
\text { tasan }\end{array}$ & $\begin{array}{c}\text { Tes } \\
\text { Akhir }\end{array}$ & Ketun- tasan & Ket \\
\hline
\end{tabular}




\begin{tabular}{|c|c|c|c|c|c|c|c|}
\hline & & & $\underset{\Xi}{\stackrel{\Xi}{\Xi}}$ & $\begin{array}{c}\text { Tdk } \\
\text { Tun- } \\
\text { tas }\end{array}$ & & $\underset{\Xi}{\stackrel{\Xi}{\Xi}}$ & $\begin{array}{c}\text { Tdk } \\
\text { Tun-tas }\end{array}$ \\
\hline 1 & Ahm & 7 & $\checkmark$ & - & 8 & $\checkmark$ & - \\
\hline 2 & Ans & 7 & $\checkmark$ & - & 8 & $\checkmark$ & - \\
\hline 3 & Ari & 6 & - & $\checkmark$ & 8 & $\checkmark$ & - \\
\hline 4 & Adi & 8 & $\checkmark$ & - & 10 & $\checkmark$ & - \\
\hline 5 & $\mathrm{Hel}$ & 8 & $\checkmark$ & - & 10 & $\checkmark$ & - \\
\hline 6 & Ime & 6 & - & $\checkmark$ & 8 & $\checkmark$ & - \\
\hline 7 & Lal & 7 & $\checkmark$ & - & 10 & $\checkmark$ & - \\
\hline 8 & M. Ab & 8 & $\checkmark$ & - & 8 & $\checkmark$ & - \\
\hline 9 & Put & 7 & $\checkmark$ & - & 9 & $\checkmark$ & - \\
\hline 10 & Ris & 6 & - & $\checkmark$ & 8 & $\checkmark$ & - \\
\hline 11 & Sel & 6 & - & $\checkmark$ & 8 & $\checkmark$ & - \\
\hline 12 & Selp & 8 & $\checkmark$ & - & 10 & $\checkmark$ & - \\
\hline 13 & Sur & 6 & - & $\checkmark$ & 6 & - & $\checkmark$ \\
\hline 14 & Sar & 6 & - & $\checkmark$ & 6 & - & $\checkmark$ \\
\hline 15 & Sit & 6 & - & $\checkmark$ & 8 & $\checkmark$ & - \\
\hline & Jumlah & 102 & 8 & 7 & 128 & 13 & 2 \\
\hline & Rata-rata & 6,80 & - & - & 8,53 & 86,66 & 13,44 \\
\hline
\end{tabular}

Tabel 4.2 : Distribusi Frekuensi Relatif Nilai-Nilai Hasil Tes Belajar Siklus 1

\begin{tabular}{cccc}
\hline No & Nilai & $\begin{array}{c}\text { Frekuensi } \\
(\mathrm{f})\end{array}$ & $\begin{array}{c}\text { Persentase } \\
(\mathrm{p})\end{array}$ \\
\hline \hline 1 & 10 & 4 & $26,67 \%$ \\
\hline 2 & 9 & 1 & $6,67 \%$ \\
\hline 3 & 8 & 8 & $53,33 \%$ \\
\hline 4 & 7 & - & - \\
\hline 5 & 6 & 2 & $13,33 \%$ \\
\hline & Jumlah & 15 & $100 \%$ \\
\hline
\end{tabular}

Berdasarkan data nilai hasil belajar siklus I yang tertera pada tabel diatas, dapat dijabarkan bahwa rata-rata nilai hasil evaluasi adalah 8,53, dengan perolehan nilai berkisar antara 6 hingga 10. Secara klasikal dari 15 peserta tes terdapat 13 orang $(86,66 \%)$ dinyatakan tuntas secara klasikal dalam mempelajari matematika konsep pengurangan bilangan bulat positif dengan bilangan bulat negatip dengan indikator kriteria ketuntasan minimal 6,5 yang disarankan kurikulum.

Berdasarkan kecenderungan perolehan nilai hasil belajar siswa pada pertemuan I dapat digambarkan dalam grafik sebagai berikut : 


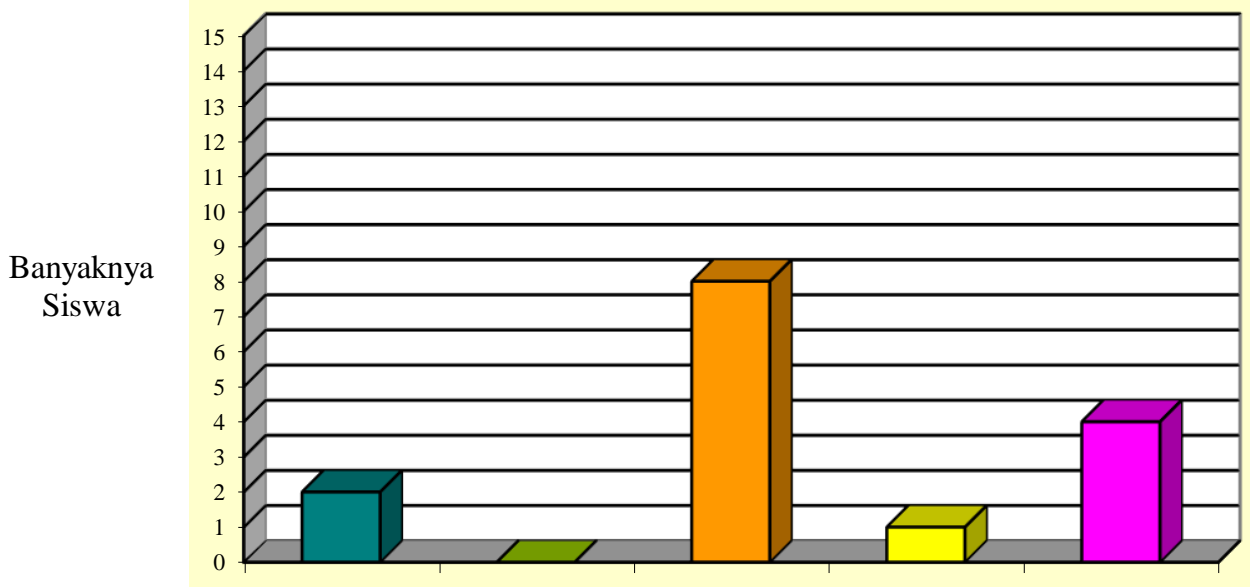

Nilai Yang Diperoleh

口Nilai $6 \quad \square$ Nilai $7 \quad \square$ Nilai $8 \quad \square$ Nilai $9 \quad \square$ Nilai 10

Gambar 4.1 : Grafik Perbandingan Nilai Hasil Belajar Siklus 1

Melihat dari nilai hasil belajar yang diperoleh siswa, penguasaan terhadap materi pengurangan bilangan bulat secara klasikal dapat dikatakan berhasil.

b. Hasil observasi aktivitas siswa

Dari hasil pengamatan melalui format observasi aktivitas siswa secara kelompok tentang pengurangan bilangan bulat menggunakan media balok garis bilangan dapat digambarkan sebagai berikut:

Tabel 4.3 : Observasi Aktivitas Siswa Dalam Kelompok Siklus 1

\begin{tabular}{|c|c|c|c|c|c|c|c|c|c|c|}
\hline \multirow{2}{*}{ No } & \multirow{2}{*}{$\begin{array}{l}\text { Inisial Nama } \\
\text { Siswa }\end{array}$} & \multicolumn{6}{|c|}{ Aspek Penilaian } & \multirow{2}{*}{ Skor } & \multirow{2}{*}{$\begin{array}{l}\text { Rata } \\
\text { Rata }\end{array}$} & \multirow{2}{*}{$\begin{array}{c}\text { Kete } \\
\text { rangan }\end{array}$} \\
\hline & & $\mathbf{1}$ & 2 & 3 & 4 & 5 & 6 & & & \\
\hline 1 & Ahm & 8 & 8 & 8 & 8 & 8 & 8 & 48 & 8,00 & Baik \\
\hline 2 & Ans & 8 & 8 & 8 & 8 & 8 & 8 & 48 & 8,00 & Baik \\
\hline 3 & Ari & 8 & 8 & 8 & 8 & 8 & 8 & 48 & 8,00 & Baik \\
\hline 4 & Adi & 7 & 7 & 8 & 8 & 8 & 8 & 46 & 7,67 & Baik \\
\hline 5 & $\mathrm{Hel}$ & 7 & 7 & 8 & 8 & 8 & 8 & 46 & 7,67 & Baik \\
\hline 6 & Ime & 7 & 7 & 8 & 8 & 8 & 8 & 46 & 7,67 & Baik \\
\hline 7 & Lal & 7 & 7 & 8 & 8 & 8 & 8 & 46 & 7,67 & Baik \\
\hline 8 & M. Ab & 6 & 6 & 7 & 7 & 7 & 8 & 41 & 6,83 & Cukup \\
\hline 9 & Put & 8 & 8 & 8 & 8 & 8 & 8 & 48 & 8,00 & Baik \\
\hline 10 & Ris & 8 & 8 & 8 & 8 & 8 & 8 & 48 & 8,00 & Baik \\
\hline 11 & Sel & 6 & 6 & 6 & 7 & 7 & 8 & 40 & 6,67 & Cukup \\
\hline 12 & Selp & 8 & 8 & 8 & 8 & 8 & 8 & 48 & 8,00 & Baik \\
\hline 13 & Sur & 8 & 8 & 8 & 8 & 8 & 8 & 48 & 8,00 & Baik \\
\hline 14 & Sar & 8 & 8 & 8 & 8 & 8 & 8 & 48 & 8,00 & Baik \\
\hline \multirow[t]{3}{*}{15} & Sit & 8 & 8 & 8 & 8 & 8 & 8 & 48 & 8,00 & Baik \\
\hline & Jumlah & 112 & 112 & 117 & 118 & 118 & 120 & 697 & 116,17 & \\
\hline & Rata-rata & 7,47 & 7,47 & 7,80 & 7,87 & 7,87 & 8,00 & 46,47 & 7,74 & \\
\hline
\end{tabular}

Berdasarkan data tabel tersebut menunjukkan bahwa pada kolom 1 yaitu pada aspek partisipasi anggota/siswa dalam kelompok saat diskusi berlangsung terdapat 2 orang siswa yang masih kurang aktif dan terlihat hanya bekerja sendiri yang 
berdampak pada kemampuan bekerja sama. Dari kolom 2 yaitu pada aspek kerja sama anggota dalam kelompok terdapat 2 orang siswa yang belum mampu bekerja sama dengan anggota kelompoknya secara baik. Pada kolom 3 yaitu pada aspek keseriusan belajar terdapat 1 orang siswa yang masih kurang memperhatikan dalam mengikuti pembelajaran. Pada kolom 4 yaitu dalam penggunaan media terlihat semua siswa nampak antusias menggunakannya, karena penggunaan media balok garis bilangan ini merupakan pengalaman baru bagi siswa dan siswa terlihat sering melangkah-langkahkan model pada balok garis bilangan. Dari kolom 4 yaitu dalam mengemukakan pendapat, secara umum terlihat semua siswa dapat melakukannya walau sesekali terdapat 2 orang siswa kadang aktif sendiri dengan aktivitasnya. Pada kolom 6 yaitu ketuntasan belajar nampak semua siswa dapat menyelesaikan semua tugas sebelum batas waktu yang ditentukan.

Saat diskusi kelompok berlangsung guru berkeliling menghampiri setiap kelompok untuk mengamati aktivitas siswa, membimbing, dan mengarahkan siswa dalam menyelesaikan LKS. Respon siswa pada awal-awal diskusi kelompok terlihat masih banyak siswa yang belum mengerti dan memahami cara berdiskusi dan menyelesaikan LKS. Semua ini disebabkan pembelajaran kooperatif dengan menggunakan media balok garis bilangan merupakan pembelajaran yang baru mereka kenal, siswa terbiasa dengan pembelajaran konvensional. Pada kelompok C masih terdapat siswa yang belum dapat berpartisipasi dan bekerja sama dengan baik, semua ini disebabkan siswa terbiasa bekerja sendiri dan lebih senang menyendiri.

Setelah melaksanakan diskusi kelompok, salah satu kelompok mempresentasikan hasil kerja kelompoknya di depan kelas. Saat pelaksanaan laporan hasil kerja kelompok semua siswa memperhatikan siswa yang membacakan. Pelaksanaan presentasi ini terlihat agak kaku karena aktivitas ini merupakan hal yang baru bagi siswa namun menyenangkan yang nampak dari keantusiasan siswa dalam mengikutinya.

c. Hasil evaluasi siklus 1

Evaluasi akhir siklus 1 dilakukan dengan memberikan tes kepada siswa yaitu evaluasi individu untuk mengetahui tingkat pemahaman siswa terhadap materi yang telah dipelajari pada pertemuan satu dan dua tentang pengurangan bilangan bulat positif dengan bilangan positif dan negatif. Pada saat evaluasi seluruh siswa hadir, pelaksanaan bersifat tertutup dan siswa tidak diperkenankan untuk bekerjasama dengan siswa lain. Saat evaluasi berlangsung guru selalu mengawasi untuk menjaga keabsahan hasil kerja siswa. Dari hasil evaluasi dapat digambarkan pada tabel berikut:

Tabel 4.4 : Nilai Tes Evaluasi Siklus 1

\begin{tabular}{llccc}
\hline \multirow{2}{*}{ No } & \multirow{2}{*}{ Nama Siswa } & \multirow{2}{*}{ Nilai } & \multicolumn{2}{c}{ Ketuntasan } \\
\cline { 4 - 5 } & & 8 & Tuntas & Tidak Tuntas \\
\hline 1 & Ahm & 8 & $\checkmark$ & - \\
\hline 2 & Ans & 8 & $\checkmark$ & - \\
\hline 3 & Ari & 10 & $\checkmark$ & - \\
\hline 4 & Adi & 10 & $\checkmark$ & - \\
\hline 5 & Hel & 8 & $\checkmark$ & - \\
\hline 6 & Ime & 10 & $\checkmark$ & - \\
\hline 7 & Lal & & & \\
\hline
\end{tabular}




\begin{tabular}{clcccc}
\hline 8 & M. Ab & 8 & $\checkmark$ & - \\
\hline 9 & Put & 9 & $\checkmark$ & - \\
\hline 10 & Ris & 8 & $\checkmark$ & - \\
\hline 11 & Sel & 8 & $\checkmark$ & - \\
\hline 12 & Selp & 10 & $\checkmark$ & - \\
\hline 13 & Sur & 6 & - & $\checkmark$ \\
\hline 14 & Sar & 6 & - & $\checkmark$ \\
\hline 15 & Sit & 8 & $\checkmark$ & - \\
\hline & $\quad$ Jumlah & 128 & 13 & 2 \\
\hline & Rata-Rata & 8,53 & - & - \\
\hline
\end{tabular}

d. Hasil refleksi siklus 1

Berdasarkan hasil paparan data dan pembahasan temuan dari beberapa observasi kegiatan pembelajaran hasil belajar siswa dan aktivitas siswa dalam pembelajaran maka dapat direfleksikan hal-hal sebagai berikut :

1) Hasil belajar siswa diketahui bahwa rata-rata kelas untuk pertemuan pertama adalah 8,53 diatas indikator ketuntasan belajar dengan ketuntasan klasikal sebanyak 13 orang $(86,66 \%)$ dengan perolehan nilai berkisar antara 6 sampai 10, hal ini disebabkan siswa telah memahami konsep pengurangan bilangan bulat positif dengan bilangan bulat negatif dan secara kelompok siswa sudah dapat bekerjasama dan dapat menjelaskan teman yang belum mengerti.

2) Aktivitas siswa dalam kelompok dipertemuan pertama berlangsung belum efektif, hal ini terlihat banyak diantara siswa yang bertanya cara menyelesaikan LKS karena menurut mereka pembelajaran seperti ini merupakan yang baru bagi mereka dan banyak diantara mereka yang belum mengerti cara menyelesaikan LKS tersebut.

Berdasarkan temuan ini, maka dapat disimpulkan bahwa penguasaan siswa sudah meningkat meski belum optimal dan tindakan kelas pada siklus 1 dinyatakan berhasil serta dapat diterima sehingga tindakan kelas ini dapat dilanjutkan ke siklus 2.

\section{b. Hasil Pelaksanaan Tindakan Kelas Siklus 2}

a. Hasil tes belajar siswa

Dari hasil tes yang dilaksanakan pada pertemuan 2 dapat digambarkan perolehan nilai hasil belajar siswa sebagai berikut :

Tabel 4.5: Nilai Tes Hasil Belajar Siklus 2

\begin{tabular}{|c|c|c|c|c|c|c|c|c|}
\hline \multirow[b]{2}{*}{ No } & \multirow[b]{2}{*}{ Nama Siswa } & \multirow{2}{*}{$\begin{array}{c}\text { Tes } \\
\text { Awal }\end{array}$} & \multicolumn{2}{|c|}{$\begin{array}{c}\text { Ketun- } \\
\text { tasan }\end{array}$} & \multirow{2}{*}{$\begin{array}{c}\text { Tes } \\
\text { Akhir }\end{array}$} & \multicolumn{2}{|c|}{$\begin{array}{c}\text { Ketun- } \\
\text { tasan }\end{array}$} & \multirow[b]{2}{*}{ Ket } \\
\hline & & & & $\begin{array}{l}\text { Tdk } \\
\text { Tun } \\
\text { tas }\end{array}$ & & & $\begin{array}{l}\text { Tdk } \\
\text { Tun- } \\
\text { tas }\end{array}$ & \\
\hline 1 & Ahm & 8 & $\bar{\checkmark}$ & - & 10 & $\bar{\checkmark}$ & - & \\
\hline 2 & Ans & 6 & - & $\checkmark$ & 10 & $\checkmark$ & - & \\
\hline 3 & Ari & 4 & - & $\checkmark$ & 8 & $\checkmark$ & - & \\
\hline 4 & Adi & 6 & $\checkmark$ & $\checkmark$ & 8 & $\checkmark$ & - & \\
\hline 5 & $\mathrm{Hel}$ & 6 & $\checkmark$ & $\checkmark$ & 10 & $\checkmark$ & - & \\
\hline 6 & Ime & 6 & - & $\checkmark$ & 10 & $\checkmark$ & - & \\
\hline
\end{tabular}




\begin{tabular}{clcccccl}
\hline 7 & Lal & 4 & - & $\checkmark$ & 8 & $\checkmark$ & - \\
\hline 8 & M. Ab & 4 & - & $\checkmark$ & 8 & $\checkmark$ & - \\
\hline 9 & Put & 6 & - & $\checkmark$ & 8 & $\checkmark$ & - \\
\hline 10 & Ris & 6 & - & $\checkmark$ & 10 & $\checkmark$ & - \\
\hline 11 & Sel & 8 & $\checkmark$ & - & 10 & $\checkmark$ & - \\
\hline 12 & Selp & 8 & $\checkmark$ & - & 10 & $\checkmark$ & - \\
\hline 13 & Sur & 6 & - & $\checkmark$ & 10 & $\checkmark$ & - \\
\hline 14 & Sar & 6 & - & $\checkmark$ & 8 & $\checkmark$ & - \\
\hline 15 & Sit & 6 & - & $\checkmark$ & 10 & $\checkmark$ & - \\
\hline & Jumlah & 90 & 5 & 10 & 138 & 15 & - \\
\hline & Rata-rata & 6,00 & - & - & 9,20 & - & - \\
\hline
\end{tabular}

Tabel 4.6 : Distribusi Frekuensi Relatif Nilai-Nilai Hasil Tes Belajar Siklus 2

\begin{tabular}{cccc}
\hline No & Nilai & $\begin{array}{c}\text { Frekuensi } \\
\text { (f) }\end{array}$ & $\begin{array}{c}\text { Persentase } \\
\text { (p) }\end{array}$ \\
\hline \hline 1 & 10 & 9 & $60,00 \%$ \\
\hline 2 & 9 & - & - \\
\hline 3 & 8 & 6 & $40,00 \%$ \\
\hline & Jumlah & 15 & $100 \%$ \\
\hline
\end{tabular}

Berdasarkan data nilai hasil belajar siklus I pertemuan 2 yang tertera pada tabel diatas, dapat dijabarkan bahwa rata-rata nilai hasil evaluasi adalah 9,20, dengan perolehan nilai berkisar antara 8 hingga 10. Secara klasikal dari 15 peserta tes terdapat 15 orang $(100 \%)$ dinyatakan tuntas dalam mempelajari matematika konsep pengurangan bilangan bulat positif dengan bilangan bulat negatif dengan indikator kriteria ketuntasan minimal 7,0 yang disarankan kurikulum.

Berdasarkan kecenderungan perolehan nilai hasil belajar siswa pada siklus 1 dan siklus 2 dapat digambarkan dalam grafik sebagai berikut :

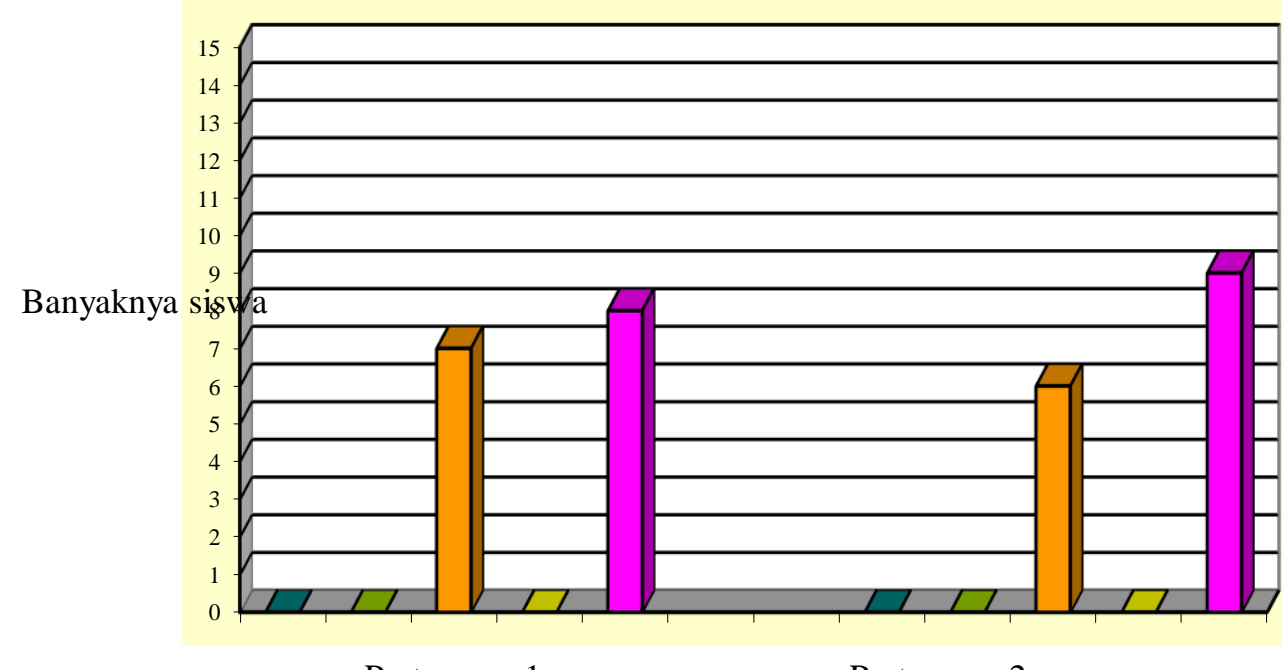

Pertemuan 1

Pertemuan 2

口Nilai $10 \quad \square$ anilai $9 \quad$ aNilai $8 \quad$ Nilai $7 \quad$ 口Nilai 6

Gambar 4.2 : Grafik Perbandingan Nilai Hasil Belajar Siklus 1 dan siklus 2 
Berdasarkan grafik tersebut diketahui perolehan nilai hasil belajar siswa dalam penguasaan materi pengurangan bilangan bulat positif dengan bilangan bulat positif dan negatif menggunakan media balok garis bilangan cenderung meningkat dan secara klasikal dapat dikatakan berhasil.

b. Hasil observasi aktivitas siswa siklus 2

Dari hasil pengamatan melalui format observasi aktivitas siswa secara kelompok tentang pengurangan bilangan bulat menggunakan media balok garis bilangan dapat digambarkan sebagai berikut :

Tabel 4.7 : Observasi Aktivitas Siswa Dalam Kelompok Siklus 2

\begin{tabular}{|c|c|c|c|c|c|c|c|c|c|c|}
\hline \multirow{2}{*}{ No } & \multirow{2}{*}{ Nama Siswa } & \multicolumn{6}{|c|}{ Aspek Penilaian } & \multirow{2}{*}{ Skor } & \multirow{2}{*}{$\begin{array}{l}\text { Rata } \\
\text { Rata }\end{array}$} & \multirow{2}{*}{$\begin{array}{l}\text { Kete } \\
\text { rangar }\end{array}$} \\
\hline & & 1 & 2 & 3 & 4 & 5 & 6 & & & \\
\hline 1 & Ahm & 8 & 8 & 8 & 8 & 8 & 9 & 49 & 8,17 & Baik \\
\hline 2 & Ans & 8 & 8 & 8 & 8 & 8 & 9 & 49 & 8,17 & Baik \\
\hline 3 & Ari & 8 & 8 & 8 & 8 & 8 & 9 & 49 & 8,17 & Baik \\
\hline 4 & Adi & 8 & 8 & 8 & 8 & 8 & 8 & 48 & 8,00 & Baik \\
\hline 5 & Hel & 8 & 8 & 8 & 8 & 8 & 8 & 48 & 8,00 & Baik \\
\hline 6 & Ime & 8 & 8 & 8 & 8 & 8 & 8 & 48 & 8,00 & Baik \\
\hline 7 & Lal & 8 & 8 & 8 & 8 & 8 & 8 & 48 & 8,00 & Baik \\
\hline 8 & M. Ab & 7 & 7 & 7 & 7 & 7 & 8 & 43 & 7,17 & Baik \\
\hline 9 & Put & 8 & 8 & 8 & 8 & 8 & 8 & 48 & 8,00 & Baik \\
\hline 10 & Ris & 8 & 8 & 8 & 8 & 8 & 8 & 48 & 8,00 & Baik \\
\hline 11 & Sel & 7 & 7 & 7 & 7 & 7 & 8 & 43 & 7,17 & Baik \\
\hline 12 & Selp & 8 & 8 & 8 & 8 & 8 & 9 & 49 & 8,17 & Baik \\
\hline 13 & Sur & 8 & 8 & 8 & 8 & 8 & 9 & 49 & 8,17 & Baik \\
\hline 14 & Sar & 8 & 8 & 8 & 8 & 8 & 9 & 49 & 8,17 & Baik \\
\hline \multirow[t]{3}{*}{15} & Sit & 8 & 8 & 8 & 8 & 8 & 9 & 49 & 8,17 & Baik \\
\hline & Jumlah & 118 & 118 & 118 & 118 & 118 & 127 & 717 & 119,5 & \\
\hline & Rata-rata & 7,87 & 7,87 & $7,8^{\prime}$ & $7,8^{\prime}$ & 7,87 & 8,47 & 47,8 & 7,97 & \\
\hline
\end{tabular}

Berdasarkan data tabel tersebut menunjukkan bahwa pada kolom 1 yaitu pada aspek partisipasi anggota/siswa dalam kelompok saat diskusi berlangsung terlihat semua siswa telah dapat berpartisipasi dengan baik yang berdampak pada proses kerjasama kelompok yang semakin baik (kolom 2). Pada kolom 3 yaitu pada aspek keseriusan belajar semua siswa semakin baik yang tergambar dari aktivitas siswa yang selalu memperhatikan dalam mengikuti pembelajaran dengan sesekali menanyakan hal yang belum dimengertinya. Pada kolom 4 yaitu dalam penggunaan media terlihat semua siswa nampak antusias menggunakannya, siswa terlihat sering melangkah-langkahkan model pada balok garis bilangan bahkan mencoba-coba dengan soal/permasalahan lain buatan sendiri. Dari kolom 4 yaitu dalam mengemukakan pendapat semua siswa dapat melakukannya baik dalam kelompok saat menyelesaikan LKS maupun dalam mengkomunikasikan/ presentasi hasil kerja kelompok. Pada kolom 6 yaitu ketuntasan belajar nampak semua siswa dapat menyelesaikan semua tugas sebelum batas waktu yang ditentukan.

Saat diskusi kelompok berlangsung guru berkeliling menghampiri kelompok yang mengalami kesulitan dalam menyelesaikan LKS. Respon siswa terhadap diskusi kelompok berlangsung lebih lancar, siswa terlihat lebih dapat bekerjasama dan saling memberikan pendapatnya. Siswa lebih memahami penerapan 
pembelajaran berkelompok, lebih aktif, dan sesekali menjelaskan pada teman yang belum memahami materi pembelajaran.

Setelah semua kelompok menyelesaikan LKS, salah satu kelompok mempresentasikan hasil kerja kelompoknya di depan kelas.Pelaksanaan Presentasi ini lebih tenang, tertib, dan lancar dibandingkan pelaksanaan presentasi pada pertemuan terdahulu.

c. Hasil evaluasi siklus 2

Evaluasi akhir siklus 1 dilakukan dengan memberikan tes kepada siswa yaitu evaluasi individu untuk mengetahui tingkat pemahaman siswa terhadap materi yang telah dipelajari pada pertemuan satu dan dua tentang pengurangan bilangan bulat positif dengan bilangan positif dan negatif. Pada saat evaluasi seluruh siswa hadir, pelaksanaan bersifat tertutup dan siswa tidak diperkenankan untuk bekerjasama dengan siswa lain. Saat evaluasi berlangsung guru selalu mengawasi untuk menjaga keabsahan hasil kerja siswa. Dari hasil evaluasi dapat digambarkan pada tabel berikut:

Tabel 4.8 : Nilai Tes Evaluasi Siklus 2

\begin{tabular}{clccc}
\hline \multirow{2}{*}{ No } & \multirow{2}{*}{ Nama Siswa } & \multirow{2}{*}{ Nilai } & \multicolumn{2}{c}{ Ketuntasan } \\
\cline { 4 - 5 } 1 & Ahm & 10 & Tuntas & Tidak Tuntas \\
\hline 2 & Ans & 10 & $\checkmark$ & - \\
\hline 3 & Ari & 8 & $\checkmark$ & - \\
\hline 4 & Adi & 8 & $\checkmark$ & - \\
\hline 5 & Hel & 10 & $\checkmark$ & - \\
\hline 6 & Ime & 10 & $\checkmark$ & - \\
\hline 7 & Lal & 8 & $\checkmark$ & - \\
\hline 8 & M. Ab & 8 & $\checkmark$ & - \\
\hline 9 & Put & 8 & $\checkmark$ & - \\
\hline 10 & Ris & 10 & $\checkmark$ & - \\
\hline 11 & Sel & 10 & $\checkmark$ & - \\
\hline 12 & Selp & 10 & $\checkmark$ & - \\
\hline 13 & Sur & 10 & $\checkmark$ & - \\
\hline 14 & Sar & 8 & $\checkmark$ & - \\
\hline 15 & Sit & 10 & $\checkmark$ & - \\
\hline & Jumlah & 138 & 15 & - \\
\hline & Rata-Rata & 9,20 & - & - \\
\hline
\end{tabular}

d. Hasil refleksi siklus 2

Berdasarkan hasil paparan data dan pembahasan temuan dari beberapa observasi kegiatan pembelajaran hasil belajar siswa dan aktivitas siswa dalam pembelajaran maka dapat direfleksikan hal-hal sebagai berikut :

1) Hasil belajar siswa diketahui bahwa rata-rata kelas untuk pertemuan pertama adalah 9,07 dan untuk siklus 2 naik mernjadi 9,20 diatas indikator ketuntasan belajar dengan ketuntasan klasikal sebanyak 15 orang $(100 \%)$ dengan perolehan nilai berkisar antara 8 sampai 10, hal ini disebabkan siswa telah memahami konsep pengurangan bilangan bulat positif dengan bilangan bulat negatif dan secara kelompok siswa sudah dapat bekerjasama dan dapat menjelaskan teman yang belum mengerti. 
2) Aktivitas siswa dalam kelompok dipertemuan pertama berlangsung belum efektif, hal ini terlihat banyak diantara siswa yang bertanya cara menyelesaikan LKS karena menurut mereka pembelajaran seperti ini merupakan yang baru bagi mereka dan banyak diantara mereka yang belum mengerti cara menyelesaikan LKS tersebut. Aktivitas siswa dalam kelompok siklus 2 nampak aktif dan kerjasama sudah baik karena siswa telah memahami cara kerja berkelompok dan menyelesaikan LKS, pada pertemuan kedua siswa tidak hanya aktif tapi juga telah dapat menjelaskan pada teman dalam kelompok yang mengalami kesulitan melalui peragaan-peragaan pada media balok garis bilangan sehingga pada pertemuan kedua terjadi perbaikan dan peningkatan aktivitas pada aspek penggunaan media, keseriusan belajar, dalam mengemukakan pendapat, dan ketuntasan belajar baik dari ketepatan maupun kecepatan penyelesaian.

\section{B. Pembahasan Hasil Penelitian Perbaikan Pembelajaran}

Berdasarkan data yang dihimpun diketahui bahwa terjadi peningkatan hasil belajar baik ketuntasan individu, ketuntasan klasikal serta nilai rata-rata kelas, pada siklus 1 ketuntasan individu hanya 13 orang meningkat menjadi 15 orang dengan ketuntasan klasikal $8,53 \%$ menjadi $100 \%$ pada siklus 2, demikian pula dengan aktivitas siswa dalam kelompok pada siklus 1 hanya 7,74 meningkat menjadi7,97 di siklus 2 .

Peningkatan hasil belajar siswa ini disebabkan siswa telah memahami konsep pengurangan bilangan cacah dan secara kelompok siswa sudah dapat bekerjasama dan dapat menjelaskan teman yang belum mengerti.

Sebagaimana yang diungkapkan Santayasa (2007: 11) bahwa model pembelajaran yang dapat diterapkan pada bidang studi hendaknya dikemas koheren dengan hakikat pendidikan bidang studi tersebut. Namun, secara filosofis tujuan pembelajaran adalah untuk memfasilitasi siswa dalam penumbuhan dan pengembangan kesadaran belajar, sehingga mampu melakukan olah pikir, rasa, dan raga dalam memecahkan masalah kehidupan di dunia nyata. Model-model pembelajaran yang dapat mengakomodasikan tujuan tersebut adalah yang berlandaskan pada paradigma konstruktivistik sebagai paradigma alternatif.

Kurniawan, (2010: 1-2) menyatakan bahwa anak SD adalah senang merasakan atau melakukan/memperagakan sesuatu secara langsung. Ditinjau dari teori perkembangan kognitif, anak SD memasuki tahap operasional konkret. Dari apa yang dipelajari di sekolah, ia belajar menghubungkan konsep-konsep baru dengan konsepkonsep lama. Berdasarkan pengalaman ini, siswa membentuk konsep-konsep tentang angka, ruang, waktu, fungsi-fungsi badan, perjenis kelamin, moral, dan sebagainya. Bagi anak SD, penjelasan guru tentang materi pelajaran akan lebih dipahami jika anak melaksanakan sendiri, sama halnya dengan memberi contoh bagi orang dewasa. Dengan demikian guru hendaknya merancang model pembelajaran yang memungkinkan anak terlibat langsung dalam proses pembelajaran.

Berdasarkan temuan ini diperoleh informasi bahwa hasil belajar siswa memiliki kecenderungan meningkat hingga mencapai indikator keberhasilan. Maka dapat disimpulkan bahwa penguasaan siswa dalam melakukan pengurangan bilangan bulat melalui penggunaan media balok garis bilangan dapat meningkat dan tindakan kelas pada siklus 2 dinyatakan berhasil. 


\section{Kesimpulan}

Berdasarkan hasil penelitian dan pembahasan dalam penelitian ini, maka dapat disimpulkan sebagai berikut :

1. Model pembelajaran media balok garis bilangan dapat meningkatkan hasil belajar siswa pada mata pelajaran matematika pada konsep mengurangkan bilangan bulat di kelas V SD Negeri 1 Teluk Betung Kecamatan Karau Kuala, hal tersebut dapat dibuktikan dari hasil belajar siswa pada siklus 1 nilai rata-rata 8,53dengan ketuntasan belajhar $86,66 \%$ dan pada siklus 2 meningkat menjadi 9,20 dengan ketuntasan belajar $100 \%$.

2. Aktivitas siswa dalam kelompok dipertemuan pertama berlangsung belum efektif, hal ini terlihat banyak diantara siswa yang bertanya cara menyelesaikan LKS karena menurut mereka pembelajaran seperti ini merupakan yang baru bagi mereka dan banyak diantara mereka yang belum mengerti cara menyelesaikan LKS tersebut. Aktivitas siswa dalam kelompok siklus 2 nampak aktif dan kerjasama sudah baik karena siswa telah memahami cara kerja berkelompok dan menyelesaikan LKS, pada pertemuan kedua siswa tidak hanya aktif tapi juga telah dapat menjelaskan pada teman dalam kelompok yang mengalami kesulitan melalui peragaan-peragaan pada media balok garis bilangan sehingga pada pertemuan kedua terjadi perbaikan dan peningkatan aktivitas pada aspek penggunaan media, keseriusan belajar, dalam mengemukakan pendapat, dan ketuntasan belajar baik dari ketepatan maupun kecepatan penyelesaian. 


\section{Bibliografi}

Alfiah. 2008. Pembelajaran Kooperatif. Jakarta:Rineka Cipta

Anita.Lie. 2004. Cooverative Learning. Jakarta:Grasindo.

Arikunto. 2007. Penelitian Tindakan Kelas. Jakarta:Bumi Aksara.

Asnan. Dianto. 2008. Rahasia Cepat Tanggap dan Cerdas Matematika untuk SD/MI Kelas 4, 5, dan 6. Surabaya: CV Pustaka Agung Harapan

Aqib,A. 2006. Penelitian Tindakan Kelas. Bandung:Yrama Widya.

Chairani. Z, 2003. Model Belajar Kooperatif Sebagai Inovasi Pembelajaran. Banjarmasin:Balai Penataran Guru.

Depdiknas. 2005. Peraturan Pemerintah Tentang Standar Nasional Pendidikan. Jakarta.

Depdiknas. 2006. Peraturan Menteri Pendidikan Nasional RI. Standar Isi untuk satuan pendidikan dasar dan menengah. Jakarta:Depdiknas

Dimyati \& Mudjiono. 2006. Belajar dan Pembelajaran. Jakarta:Rineka Cipta.

Hamalik.Oemar. 2008. Kurikulum dan Pembelajaran. Jakarta:PT Rajagrafindo Persada

Hergenhahn \& Olson MH. 2008. Tanpa tahun. Teori Belajar. Terjemahan oleh Tri Wibowo B.S. 2008:Kencana.

Ibrahim, Muslimin dkk. 2000. Pembelajaran Kooperatif. Surabaya: UNESA. University press.

Karso. 2000. Pendidikan Matematika 1. Jakarta:Universitas Terbuka.

Masrukan. 2004. Matematika dan Alat Peraga. Fasilitator : 31

Mikarsa. 2008. Pendidikan Anak di SD. Jakarta:Universitas Terbuka.

Muhibbin Syah. 2006. Psikologi Belajar. Jakarta:PT RajaGrafindo Persada.

Muhsetyo.Gatot 2008. Pembelajaran Matematika SD. Jakarta:Universitas Terbuka.

Mulyasa. 2006. Menjadi Guru Profesional. Bandung:PT Remaja RosdaKarya

Ngapiningsih. 2009. Matematika Kelas 4. Klaten:PT Macanan Jaya Cemerlang

Nurhadi. 2004. Kurikulum 2004 Pertanyaan dan Jawaban. Jakarta:Grasindo 
Sadiman. Arief.S. dkk. 2008. Media Pendidikan. Jakarta:PT Raja Grafindo Persada.

Sanjaya, Wina. 2007. Strategi Pembelajaran Berorientasi Standar Proses. Jakarta:Perdana Media Group.

Setiawati. Endang dan Uzer Usman. 2001. Optimalisasi Kegiatan Belajar Mengajar. Bandung:Remaja Rosdakarya.

Slavin. R.E. 1995. Cooperative Learning: Theory, Research, and Practice. Boston. MA: Allyn and Bacon

Suharsimi. 2007. Penelitian Tindakan Kelas. Jakarta:PT Bumi Aksara

Sunarroso. 2008. Belajar Praktis Aljabar. Surakarta:PT Era Pustaka Utama.

Tara. E.O. 2008. Matematika Kelas IV untuk SD/MI. Klaten:Intan Pariwara.

Thoha.M. Chabib. 2003. Teknik Evaluasi Pendidikan. Jakarta:PT RajaGrafindo Persada

Thoifuri, 2008. Menjadi Guru Inisiator. Semarang:RaSAIL Media Group

Undang-Undang Republik Indonesia Nomor 20 Tahun 2003. Tentang Sistem Pendidikan Nasional. 2003. Jakarta:Mendiknas

Winataputra. US. 2008. Teori Belajar dan Pembelajaran. Jakarta:Universitas Terbuka

Yamin. Martinis. 2008. Paradigma Pendidikan Konstruktivistik. Jakarta:Gaung Persada Press 